\title{
Water Deficit Irrigation Impacts on Antioxidant Metabolism Associated with Freezing Tolerance in Creeping Bentgrass
}

\author{
Li-Juan Zhang \\ Shenzhen Tourism College, Jinan University, Shenzhen, Guangdong 518053, P.R. China \\ Tian-Xiu Zhong, Li-Xin Xu, and Lie-bao Han ${ }^{1}$ \\ Turfgrass Research Institute, Beijing Forestry University, Beijing 100083, P.R. China \\ Xunzhong Zhang ${ }^{1}$ \\ Department of Crop and Soil Environmental Sciences, Virginia Polytechnic Institute and State \\ University, Blacksburg, VA 24061
}

\begin{abstract}
AdDitional INDEX wORDs. cold, drought, free radicals, osmotic adjustment, turfgrass
ABSTRACT. Soil water deficit impacts cold acclimation and freezing tolerance in creeping bentgrass (Agrostis stolonifera L.), but the mechanisms underlying have not been well understood. The objectives of this study were to investigate the effects of deficit irrigation before and during cold acclimation on osmoprotectants, antioxidant metabolism, and freezing tolerance in creeping bentgrass. The grass was subjected to three-soil moisture levels: well-watered $[\mathbf{1 0 0} \%$ container capacity $(\mathrm{CC})]$, deficit irrigation induced-mild drought stress $(60 \% \mathrm{CC})$, and severe drought stress $(30 \%$ CC) for 35 days including 14 days at $24 / 20^{\circ} \mathrm{C}$ (day/night) and then 21 days under cold acclimation treatment $\left(2^{\circ} \mathrm{C}\right.$ ) in growth chambers. Leaf proline and total soluble sugar (TSS) levels were higher in the grass under mild drought stress relative to that under severe drought stress. Superoxide $\left(\mathrm{O}_{2}^{-}\right)$, hydrogen peroxide $\left(\mathrm{H}_{2} \mathrm{O}_{2}\right)$, and malondialdehyde (MDA) content were higher in the grass under severe drought relative to that under well-watered and mild drought stress at day 35. Mild drought stress increased catalase (CAT) and guaiacol peroxidase (POD) activity, induced new isoforms and increased band intensities of superoxide dismutase (SOD), CAT, and POD during cold acclimation (days 14 to 35). No differences in osmoprotectants, antioxidant metabolism, and freezing tolerance were found between mild drought and well-watered treatments. The results of this study suggest deficit irrigation-induced mild drought stress in late fall and winter could induce accumulation of osmoprotectants and improve antioxidant metabolism, and freezing tolerance, but severe drought stress could reduce freezing tolerance of creeping bentgrass in the region with limited precipitation.
\end{abstract}

Creeping bentgrass has been widely used as a cool-season turfgrass species for golf course greens, tees, and fairways in cool-humid and transitional climate zones due to its high density and tolerance to short mowing (Wang et al., 2012). It has excellent cold resistance and could tolerate temperatures as low as $-35^{\circ} \mathrm{C}$ (Gusta et al., 1980). However, creeping bentgrass has suffered winter-kill in some temperate regions such as in northern China. Winter-kill is a general term that is used to define turf loss during the winter and can be caused by a combination factors including desiccation, crown hydration, low temperatures, ice cover, and snow mold (Beard, 1973; Bhowmik et al., 2008). Winter-kill significantly damages the quality of sports surface, especially in golf greens, tees, and fairways.

In northern China such as Beijing area, the daily low temperatures are $8,0,-6,-9,-6$, and $0{ }^{\circ} \mathrm{C}$ and the monthly precipitations are $2.3,0.8,0.2,0.3,0.6$, and $0.9 \mathrm{~cm}$ in October, November, December, January, February, and March, respectively, based on 30-year average. It appears that limited precipitation in late fall and winter may cause severe drought stress and could be a major factor causing winter-kill because the temperatures are well above killing temperature for creeping

Received for publication 20 Oct. 2014. Accepted for publication 18 May 2015. This work was funded by China 863 Plan (No. 2013AA102607) and the Fundamental Research Funds for the Central Universities (No. BLX2012034). ${ }^{1}$ Corresponding author. E-mail: hanliebao@163.com or xuzhang@vt.edu. bentgrass in this area. Because of severe shortage of water resource and a high cost of irrigation water, golf course managers in this region are reluctant to water the grass in late fall through winter. Previous studies have shown that deficit irrigation could not only improve creeping bentgrass tolerance to stress but also significantly reduce cost of irrigation water (Ervin et al., 2009; Huang et al., 2014). However, little study has been reported on effect of deficit irrigation or mild drought stress before and during cold acclimation impacts on defensive metabolism and freezing tolerance of creeping bentgrass.

Creeping bentgrass undergoes cold acclimation, which is induced by a combination of reduced photoperiod and temperatures in late fall (Dionne et al., 2001a, 2001b; Hoffman et al., 2010). Cool-season turfgrasses require temperatures between 0 and $7{ }^{\circ} \mathrm{C}$ for $2-3$ weeks to initiate the cold acclimation process. Second stage of cold acclimation is induced by subzero temperatures (Beard, 1973). Soil moisture status affects turfgrass cold acclimation process and thus cold tolerance (Beard, 1973). Previous studies have shown that mild drought stress can induce osmotic adjustment and antioxidant defenses in creeping bentgrass under normal temperature conditions (DaCosta and Huang, 2006, 2007; Fu and Dernoeden, 2009; McCann and Huang, 2007). Reduced soil water content may facilitate cold hardiness in st. augustinegrass [Stenotaphrum secundatum (Walt) Kuntze (Maier et al., 1994)] and arabidopsis [Arabidopsis thaliana (L.) Heynh (Mäntylä et al., 1995)]. This suggests 
preconditioning of the grass under mild drought stress before cold acclimation may improve plant defensive metabolism and freezing tolerance.

Environmental stress may damage plant cells by the accumulation of toxic reactive oxygen species (ROS), including $\mathrm{O}_{2}^{-}, \mathrm{H}_{2} \mathrm{O}_{2}$, hydroxyl radicals $(\mathrm{OH} \cdot)$, and singlet oxygen $\left({ }^{1} \mathrm{O}_{2}\right)$ (Apel and Hirt, 2004; Møller et al., 2007). The overproduction of ROS may damage lipids, proteins, and nuclei acids, resulting in plant senescence and death (Smirnoff, 1993). Plants have developed antioxidant defense mechanisms to eliminate ROS and prevent oxidative damage. Antioxidant enzymes, such as SOD (EC 1.15.1.1), CAT (EC 1.11.1.6), POD (EC 1.11.1.7), and ascorbate peroxidase [APX (EC 1.11.1.11)] protect plants against oxidative stress (Blokhina et al., 2003). SOD constitutes the first line of defense against ROS by dismutating the $\mathrm{O}_{2}{ }^{-}$to $\mathrm{H}_{2} \mathrm{O}_{2}$ (Apel and Hirt, 2004), which is finely regulated by CAT, POD, and APX (Wang et al., 2012). Various antioxidant metabolites and enzymes may work coordinately in suppressing ROS toxicity under stressful environments.

The level of antioxidant activity and gene expression is regulated in response to abiotic stresses such as drought and low temperature stresses (Jiang et al., 2010; Menezes-Benavente et al., 2004; Zhou et al., 2012). Catalase is induced by low temperature and an essential enzyme to protect mitochondria against chilling stress. The regulation in antioxidant enzyme activity and isozyme expression under adverse environments is closely related to plant tolerance to abiotic stresses (Allen, 1995; Mittler, 2002).

Plant may undergo osmotic adjustment in response to drought and cold stress (Hoffman et al., 2014; Huang et al., 2014). Accumulation of various osmoprotectants or compatible solutes, such as soluble proteins, simple sugars, and amino acids, in the cell during drought stress and cold acclimation improve plant tolerance to stresses (Ball et al., 2002; Blokhina et al., 2003; Hoffman et al., 2014; Shi et al., 2012).

Deficit or water-saving irrigation cannot only save water and reduce cost but also create mild drought stress which may improve defensive metabolism (Ervin et al., 2009; Huang et al., 2014). Severe drought stress occurred without irrigation in late fall in the region with limited precipitation may weaken defensive metabolism before and during cold acclimation and reduces winter survival of creeping bentgrass. Our hypothesis was that mild drought stress induced by deficit irrigation before and during cold acclimation would improve levels of osmoprotectants, antioxidant metabolism, and freezing tolerance when compared with severe drought stress (occurring in the region with limited precipitation and without irrigation in late fall and winter). In addition, mild drought stress treatment may improve osmorprectants, antioxidant metabolism, and freezing tolerance when compared with well-watered treatment.

The objectives of this study were to examine effects of three soil moisture levels (well-watered, mild drought stress, and severe drought stress) $14 \mathrm{~d}$ before and during $21 \mathrm{~d}$ of cold acclimation $\left[2{ }^{\circ} \mathrm{C}\right.$ (days 14 to 35 )] on osmoprotectants, antioxidant metabolism, and freezing tolerance, and investigate if mild drought stress induced by deficit irrigation could improve plant freezing tolerance when compared with wellwatered and severe drought stress regimes.

\section{Materials and Methods}

Plant materials and growth conditions. Seeds of creeping bentgrass (cv. T-1), commonly used for golf putting greens in this region, were sown in plastic pots (16-cm diameter and $14.5-\mathrm{cm}$ deep) filled with a mixture of 4 peat: 2 vermiculite: 1 fine sand (by volume) at $10 \mathrm{~g} \cdot \mathrm{m}^{-2}$ pure live seed on $20 \mathrm{Dec}$. 2011. The grass was grown in a greenhouse $\left[24 \pm 2 / 16 \pm 2{ }^{\circ} \mathrm{C}\right.$ (day/night), $60 \%$ to $65 \%$ relative humidity (RH), 12-h photoperiod, and photosynthetically active radiation $(P A R)$ at 350 $\mu \mathrm{mol} \cdot \mathrm{m}^{-2} \cdot \mathrm{s}^{-1}$ at the level of the plant canopy], watered every $3 \mathrm{~d}$ to prevent water deficit, and half-strength Hoagland's nutrient solution was provided every week. The greenhouse was covered with a dark plastic sheet and equipped with artificial lamps (YZ28-T5; NVC Lighting Technology Corp., Huizhou, China) to provide uniform light environment. On 17 Mar. 2012, the pots were transferred to a growth chamber system with day/ night temperatures of $24 / 20^{\circ} \mathrm{C}, 65 \% \mathrm{RH}, 12$-h photoperiod, and $P A R$ at $350 \mu \mathrm{mol} \cdot \mathrm{m}^{-2} \cdot \mathrm{s}^{-1}$. All the pots had the same soil moisture level (38\%) before the drought treatment as determined using a soil moisture meter (Delta-T Devices, Cambridge, England) (Nemali et al., 2007). The grass was grown for 4 weeks before treatments were initiated on 17 Apr. 2012.

Treatments AND SAmpling. The grass was subjected to three soil moisture treatments for $35 \mathrm{~d}$ from 17 Apr. (day 0) to 21 May 2012 (day 35). The three soil moisture treatments included: 1) well-watered $[100 \% \mathrm{CC}, 38 \%$ volumetric water content (VWC)]; 2) mild drought stress $(60 \% \mathrm{CC}, \mathrm{VWC}$ was reduced gradually from $38 \%$ to $23 \%$ from days 0 to 14 and maintained at this level from days 15 to 35$)$; and 3$)$ severe drought stress (30\% $\mathrm{CC}$ from days 15 to 35 , VWC was reduced gradually from $38 \%$ to $12 \%$ from days 0 to 14 and remained at this level from days 15 to 35$)$. The grass was subjected to temperature at $24 / 20{ }^{\circ} \mathrm{C}$ (day/night), RH at $60 \%, P A R$ at $350 \mu \mathrm{mol} \cdot \mathrm{m}^{-2} \cdot \mathrm{s}^{-1}$, and $12-\mathrm{h}$ photoperiod from days 0 to 14 , and then cold acclimation temperature at $2{ }^{\circ} \mathrm{C}$ (day and night), $\mathrm{RH}$ at $65 \%, P A R$ at 200 $\mu \mathrm{mol} \cdot \mathrm{m}^{-2} \cdot \mathrm{s}^{-1}$, and 10 -h photoperiod from days 15 to 35 . The low $\mathrm{RH}(45 \%)$ was used at the first $5 \mathrm{~d}$ to enhance dry-down process.

The water content of the soil was determined according to Black (1965). For well-watered regime, soil water content was $32.2 \%$ from days 0 to 35 . For mild drought stress regime, soil water content was reduced gradually with $32.2 \%$ at day 0 , $29.1 \%$ at day $2,26.2 \%$ at day $4,24.5 \%$ at day $6,22.1 \%$ at day 8 , $21.1 \%$ at day $10,19.8 \%$ at day $12,19.0 \%$ at day 14 , and maintained at this level from days 15 to 35 . For severe drought stress regime, soil water content was reduced gradually with $32.1 \%$ at day $0,28.9 .0 \%$ at day $2,24.4 \%$ at day $4,20.3 \%$ at day $6,17.5 \%$ at day $8,14.4 \%$ at day $10,12.5 \%$ at day $12,10.2 \%$ at day 14 , and maintained at this level from days 15 to 35 . Mild drought stress treatment was designed to simulate the situation where deficit irrigation was applied to reduce amount of irrigation water and cost when compared with normal irrigation practice. Severe drought stress was designed to represent the situation where no irrigation was provided in the area with limited precipitation in late fall and winter months. Irrigation was carried out based on pot weight and soil moisture content measurement. Soil moisture content was measured every $2 \mathrm{~d}$ and adjusted to the designed levels.

Leaf tissues were sampled on 17 Apr. (day 0), 1 May (day 14), and 21 May (day 35) and immediately frozen with liquid nitrogen and stored at $-80{ }^{\circ} \mathrm{C}$ until analysis. Subsamples from frozen samples were collected and weighed [fresh weight (FW)] and then dried at $75^{\circ} \mathrm{C}$ for $72 \mathrm{~h}$ to determine dry weight (DW). Leaf moisture content (percentage) was determined and used for calculating proline and total soluble protein content (TSP) on a DW basis. The dry leaf tissues were used for analysis of TSS. 
LT $_{50}$ DETERMination. Freezing injury was assessed on 21 May 2012 by measuring the lethal low temperature $\left(\mathrm{LT}_{50}\right)$ of leaves using a modified version of the method described by Zhang et al. (2008). The $\mathrm{LT}_{50}$ was determined at the end of the experiment (21 May 2012). Fresh leaves (100 mg) were detached, washed briefly in deionized water $\left(\right.$ d.i. $\left.\mathrm{H}_{2} \mathrm{O}\right)$, wrapped immediately in damp gauze, and then placed in a refrigerator overnight at $4{ }^{\circ} \mathrm{C}$. Then, they were put into a controlled temperature cryo-bath whose temperature was then lowered at a rate of $2{ }^{\circ} \mathrm{C}$ per hour and held for $60 \mathrm{~min}$ at each of the experimental temperatures $\left(0,-4,-8,-12,-16,-20\right.$, and $\left.-24{ }^{\circ} \mathrm{C}\right)$. Four replicates were removed at each temperature and transferred to the refrigerator immediately at $4{ }^{\circ} \mathrm{C}$ overnight to thaw. On the third day, $10-\mathrm{mL}$ d.i. $\mathrm{H}_{2} \mathrm{O}$ was added to the test tubes and thawing leaves were then shaken for $4 \mathrm{~h}$ to extract electrolytes from lysed cells. The electrical conductivity (EC) of the solution was measured (EC1) using a conductivity meter (Leici Instrument Corp., Shanghai, China). The samples were then killed by autoclaving at $120^{\circ} \mathrm{C}$ for $15 \mathrm{~min}$, and then the $\mathrm{EC}$ was determined again (EC2). Electrolyte leakage [EL (percent)] was calculated using the formula: $\mathrm{EL}=(\mathrm{EC} 1 / \mathrm{EC} 2) \times$ 100. The relationship of EL with temperature fitted a threeparameter logistic model (1) using Sigma Plot 10.0.1 (Systat Software, San Jose, CA) as follows:

$$
E=\frac{K}{1+a e^{-b t}}
$$

where $E$ represents the rate of cell damage (percent), $K$ represents the maximum rate of cell damage (percent); $t$ represents temperature (degrees Celsius); $e$ is the base of the natural logarithm; $a$ and $b$ are the equation parameters.

The $\mathrm{LT}_{50}$ (the curve inflection point) resulting in $50 \% \mathrm{EL}$ was determined from the regression Eq. [1] for each treatment:

$$
\mathrm{LT}_{50}=\frac{\ln (a)}{b}
$$

LEAF RELATIVE WATER CONTENT (RWC). The leaf RWC was determined using the method described by DaCosta and Huang (2007) with minor modifications. Briefly, leaf samples $(\approx 100$ $\mathrm{mg}$ ) were collected and weighed immediately to determine FW. The leaf sample was cut into $\approx 5$ - $\mathrm{mm}$ sections and placed in a 2-mL microcentrifuge tube with $1.8 \mathrm{~mL}$ d.i. $\mathrm{H}_{2} \mathrm{O}$. After $\approx 18 \mathrm{~h}$ at $4{ }^{\circ} \mathrm{C}$, the leaf sample was blotted dry and weighed immediately to determine turgid weight (TW). The leaf tissue was then dried at $75^{\circ} \mathrm{C}$ for $72 \mathrm{~h}$ to determine DW. The leaf RWC was calculated by the following equation: RWC (percent) $=[(\mathrm{FW}-\mathrm{DW}) /$ $(\mathrm{TW}-\mathrm{DW})] \times 100$. Chlorophyll content was determined according to Jiang et al. (2010).

LeAF PROLINE AND TSS CONTENT. The leaf proline content was determined as described by DaCosta and Huang (2006). The TSS content was estimated using anthrone-sulfuric acid (Shi et al., 2012).

LEAF ROS CONTENT AND LIPID PEROXIDATION. The production of $\mathrm{O}_{2}{ }^{-}$was measured using a modified version of the method described by Jiang and Zhang (2001). The $\mathrm{H}_{2} \mathrm{O}_{2}$ content was determined using a method described by Sergiev et al. (1997) with some modifications. Frozen leaves (100 mg) were pulverized into a fine powder in liquid nitrogen and then extracted in $2 \mathrm{~mL}$ trichloroacetic acid $(0.1 \%, \mathrm{w} / \mathrm{v})$. The extract was centrifuged at $12,000 \mathrm{~g}_{\mathrm{n}}$ for $20 \mathrm{~min}$ at $4{ }^{\circ} \mathrm{C}$. Then $1 \mathrm{~mL}$ of the resulting supernatant was mixed with $1 \mathrm{~mL}$ potassium phosphate $(10 \mathrm{~mm}$,
$\mathrm{pH} 7.0$ ) and $2 \mathrm{~mL}$ potassium iodide $(1 \mathrm{M})$. The absorbance of the mixture was measured at $390 \mathrm{~nm}$. The $\mathrm{H}_{2} \mathrm{O}_{2}$ content was estimated based on a standard curve of $\mathrm{H}_{2} \mathrm{O}_{2}$.

Lipid peroxidation of the leaf tissue was measured in terms of MDA content using the method of Kuk et al. (2003). The concentrations of MDA were calculated using an extinction coefficient of $155 \mathrm{mM}^{-1} \cdot \mathrm{cm}^{-1}$.

LEAF TSP AND ANTIOIXDANT ENZYME ACTIVITY. Frozen leaves (100 mg) were ground into fine powder in liquid nitrogen and $2 \mathrm{~mL}$ of extraction buffer [ $50 \mathrm{~mm}$ potassium phosphate, $\mathrm{pH} 7.0$, $1 \mathrm{~mm}$ ethylenediaminetetraacetic acid (EDTA), 1\% polyvinylpyrrolidone (PVP-40), $1 \mathrm{~mm}$ dithiothreitol, and $1 \mathrm{~mm}$ phenylmethylsulfonyl] was added. The sample was then centrifuged at $15,000 g_{n}$ for $20 \mathrm{~min}$ at $4{ }^{\circ} \mathrm{C}$, and the supernatant obtained was used for an enzyme assay. The TSP content was determined by the method of Bradford (1976) using bovine serum albumin as a protein standard. All enzyme assays were completed in the same day as the TSP assay. The SOD enzyme assays used a microplate reader (Multiskan GO; Thermo Fisher Scientific, Waltham, MA), while the other used an ultraviolet-visible spectrophotometer (BioMATE 3S, Thermo Fisher Scientific).

Total SOD activity was measured using a modification of the methods described by Banowetz et al. (2004). The assay medium contained $40 \mu \mathrm{L}$ crude enzyme extraction and $250 \mu \mathrm{L}$ Pierazine-N,N'-bis [2-ethanesulfonic acid (Pipes)] buffers [50 mM, pH 7.5, containing $0.4 \mathrm{~mm} o$-dianisidine, $0.5 \mathrm{~mm} N, N$, $N^{\prime}, N^{\prime}$-tetramethylethylenediamine (TEMED), and $26 \mu \mathrm{M}$ riboflavin]. The absorbance at $450 \mathrm{~nm}$ was read on a microplate reader initially and $30 \mathrm{~min}$ after the plate had been subjected to light. The SOD activity was calculated based on the standard curve and expressed as unit per milligram protein.

The activity of CAT was determined according to the methods of Aebi (1984) by recording the decrease in absorbance at $240 \mathrm{~nm}$ for $1 \mathrm{~min}$. The reaction mixture contained $2.84 \mathrm{~mL}$ potassium phosphate buffer (50 mM, pH 7.0), $30 \mu \mathrm{L} \mathrm{H}_{2} \mathrm{O}_{2}(1.5 \mathrm{M})$, and $0.1 \mathrm{~mL}$ enzyme extract.

The activity of POD was assayed by an increase in absorbance at $470 \mathrm{~nm}$ for 1 min using the method of Kochhar et al. (1979). The reaction mixture contained $1 \mathrm{~mL}$ potassium phosphate buffer (50 mM, pH 7.0), $1 \mathrm{~mL} \mathrm{H}_{2} \mathrm{O}_{2}(0.3 \%$, w/v), $0.95 \mathrm{~mL}$ guaiacol $(0.2 \%, \mathrm{w} / \mathrm{v})$, and $50 \mu \mathrm{L}$ enzyme extraction. The reaction was activated by adding $\mathrm{H}_{2} \mathrm{O}_{2}$.

The activity of APX was measured by recording the decrease in absorbance at $290 \mathrm{~nm}$ for $1 \mathrm{~min}$, and calculated using an extinction coefficient of $2.8 \mathrm{~mm}^{-1} \cdot \mathrm{cm}^{-1}$ (Nakano and Asada, 1981). The reaction mixture contained $2.82 \mathrm{~mL}$ of potassium phosphate buffer (50 mM, pH 7.0), $30 \mu \mathrm{L}$ ascorbic acid (50 mM), $30 \mu \mathrm{L}$ EDTA $(10 \mathrm{~mm}), 0.1 \mathrm{~mL}$ enzyme extract, and $0.1 \mathrm{~mL}$ $\mathrm{H}_{2} \mathrm{O}_{2}(10 \mathrm{~mm})$. The reaction was initiated by adding $\mathrm{H}_{2} \mathrm{O}_{2}$.

AnTIOXIDANT ISOZYME EXPREssion. Isoforms of SOD, CAT, POD, and APX were separated on nondenaturating native polyacrylamide gel electrophoresis. The procedure for protein extraction was the same as for TSP, and the protein was extracted from $0.2 \mathrm{~g}$ frozen leaves with $1 \mathrm{~mL}$ extraction buffer. Native PAGE was conducted using a mini-gel system (Liuyi Instrument Corp., Beijing, China) at $4{ }^{\circ} \mathrm{C}, 120 \mathrm{~V}$ for $90 \mathrm{~min}$, but sodium dodecyl sulfate was not used. In each lane, $20 \mu \mathrm{g}$ of protein was loaded, and 10\% resolving gel and 4\% stacking gel were used for SOD and POD, while 7\% resolving gel and 3\% stacking gel were applied for CAT.

The gels of SOD were stained according to a modified version of the method of Beauchamp and Fridovich (1971). 
After finishing the running, the gels were incubated in the dark for $25 \mathrm{~min}$ in $50 \mathrm{~mm}$ potassium phosphate buffer (pH 7.5) containing $2.5 \mathrm{~mm}$ nitroblue tetrazolium. After being washed briefly twice with the same buffer, the gels were soaked in $50 \mathrm{~mm}$ potassium phosphate buffer ( $\mathrm{pH}$ 7.5) containing $30 \mu \mathrm{M}$ riboflavin and $0.4 \%$ TEMED in the dark for $40 \mathrm{~min}$. The gels were then exposed to dim light for $15 \mathrm{~min}$ at room temperature with gentle agitation until bands appeared, and then the reaction was ended by transferring to $1 \%(\mathrm{v} / \mathrm{v})$ acetic acid.

The isoforms bands of CAT were visualized using the methods described by Woodbury et al. (1971). After finishing the running, the gels were soaked in $3.27 \mathrm{~mm} \mathrm{H}_{2} \mathrm{O}_{2}$ for $20 \mathrm{~min}$, rinsed twice briefly, and then submerged in the freshly prepared solution containing $1 \%(\mathrm{w} / \mathrm{v})$ ferric chloride and $1 \%(\mathrm{w} / \mathrm{v})$ potassium ferricyanide until achromatic bands appeared.

Isoforms of POD were revealed using the method by Fielding and Hall (1978). First, the $\mathrm{pH}$ of gels was lowered by soaking in potassium phosphate buffer $(10 \mathrm{~mm}$, containing $150 \mathrm{~mm}$ sodium chloride, $\mathrm{pH}$ 6.0) for $45 \mathrm{~min}$. The gels were then washed briefly with $100 \mathrm{~mm}$ PBP (pH 6.4), then dyed in $100 \mathrm{~mm}$ potassium phosphate buffer (pH 6.4) containing $20 \mathrm{~mm}$ guaiacol and 5.55 $\mathrm{mm}_{2} \mathrm{O}_{2}$ for 10 min until the bands were clearly visible. The reaction was ended by washing the gels with DI $\mathrm{H}_{2} \mathrm{O}$.

EXPERIMENTAL DESIGN AND STATISTICAL ANALYSIS. A completely randomized block design was used with three soil moisture treatments (well-watered, mild drought stress, and severe drought stress). Each treatment was replicated for four times. The data were subjected to one-way analysis of variance using SPSS (version 16.0; IBM Corp., Armonk, NY). Mean separations for each sampling date were performed using the Fisher's protected least significant difference at a 0.05 significance level.

\section{Results}

$\mathbf{L T}_{50}$, EL, RWC, AND CHLOROPHYLL CONTENT. Soil moisture treatments affected $\mathrm{LT}_{50}$ (Fig. 1A). The $\mathrm{LT}_{50}$ values were calculated based for the following equations:

For the control, the equation for $\mathrm{LT}_{50}$ was:

$$
E=\frac{96.0313}{1+169.5076 e^{-(-0.2928) t}}, \quad \mathrm{LT}_{50}=\frac{\ln (a)}{b}=-17.53
$$

For mild drought stress treatment, the equation was:

$$
E=\frac{104.7889}{1+59.8135 e^{-(-0.2256) t}}, \quad \text { LT50 }=\frac{\ln (a)}{b}=-18.14
$$

For severe drought stress, the equation was: 0.05 .
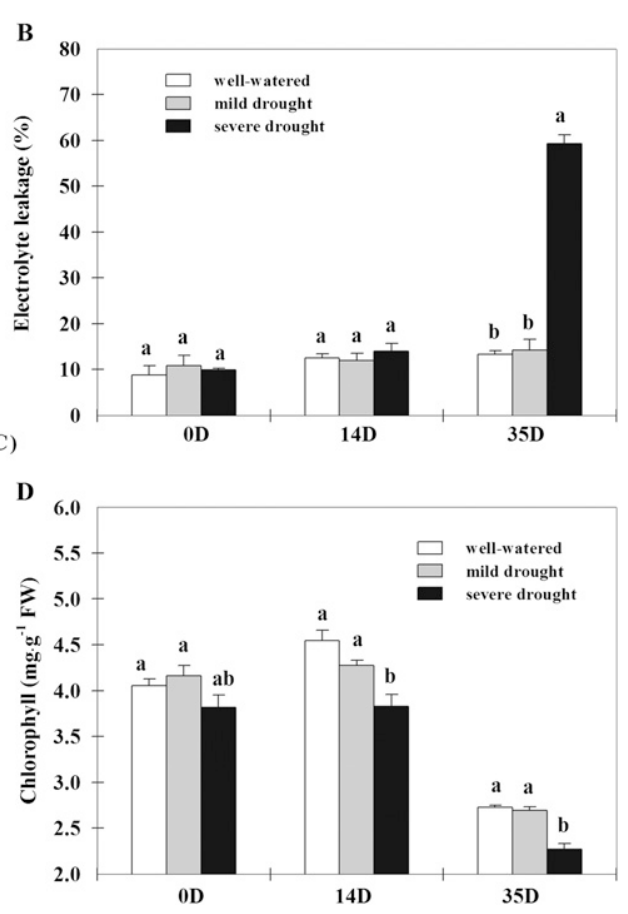

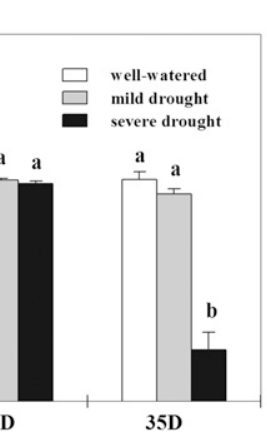
same letters are not significantly different based on the Fisher's protected least significance difference test at $P \leq$

$$
E=\frac{95.4930}{1+110.0871 e^{-(-0.2858) t}}, \quad \text { LT50 }=\frac{\ln (a)}{b}=-16.45
$$

Mild drought stress resulted in a greater freezing tolerance (lower $\mathrm{LT}_{50}$ ) when compared with severe drought stress treatment. No difference in $\mathrm{LT}_{50}$ was observed between wellwatered and mild drought stress treatment under cold acclimation. Severe drought stress increased plant injury (a higher EL) during cold acclimation [from days 14 to 35 (Fig. 1B)]. The EL under well-watered and mild drought stress remained unchanged from days 14 to 35 . At day 35, the EL was 4-fold greater in the grass under severe drought stress relative to that under either well-watered or mild drought stress conditions.

The RWC of the grass under severe drought decreased during cold acclimation [from days 14 to 35 (Fig. 1C)]. The RWC of the grass under well-watered and mild drought stress remained unchanged during cold acclimation. At day 35, the RWC was $40 \%$ less in the grass under severe drought stress relative to that under either well-watered or mild drought stress conditions.

Soil moisture treatments had no impact on chlorophyll content from days 0 to 14 (Fig. 1D). From days 14 to 35, chlorophyll content was reduced by $33 \%$ under well-watered, $35 \%$ under mild drought, and $41 \%$ under severe drought stress conditions, respectively. Severe drought stress treatment reduced chlorophyll content relative to well-watered and mild drought stress treatments as measured at day 35 .

LEAF PROLINE, TSS, AND TSP CONTENT. The proline content increased in response to drought stress from days 0 to 14 (Fig. 2A). At day 14, the grass under mild and severe drought stress treatments had higher proline content than that under well-watered conditions. During cold acclimation, the proline 
A

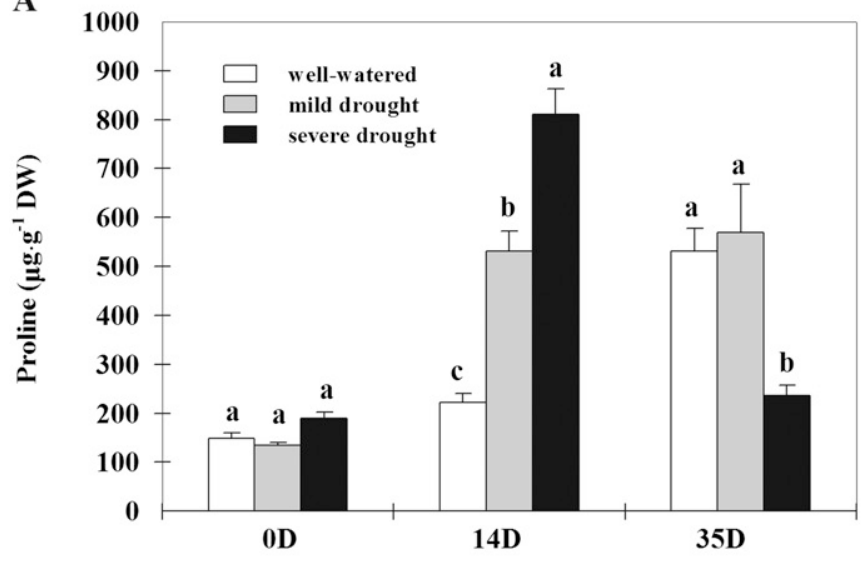

B

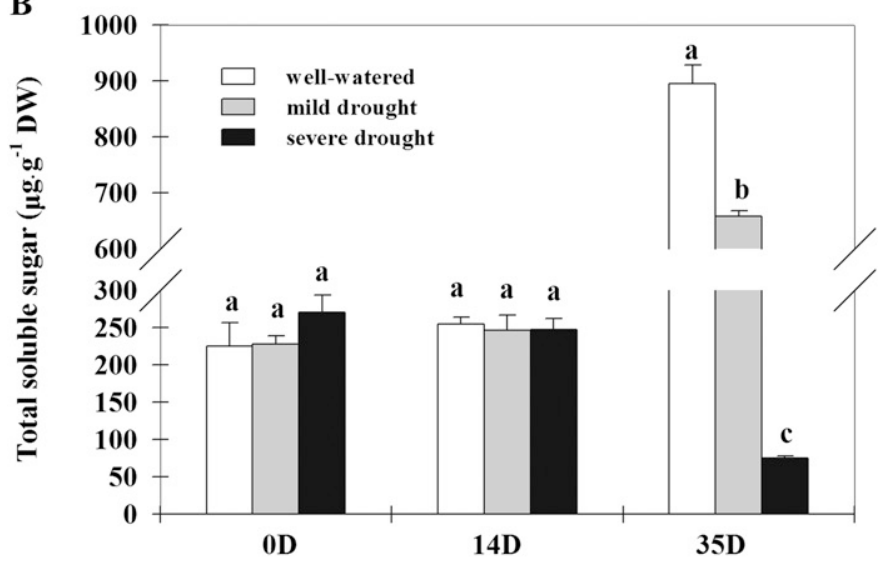

C

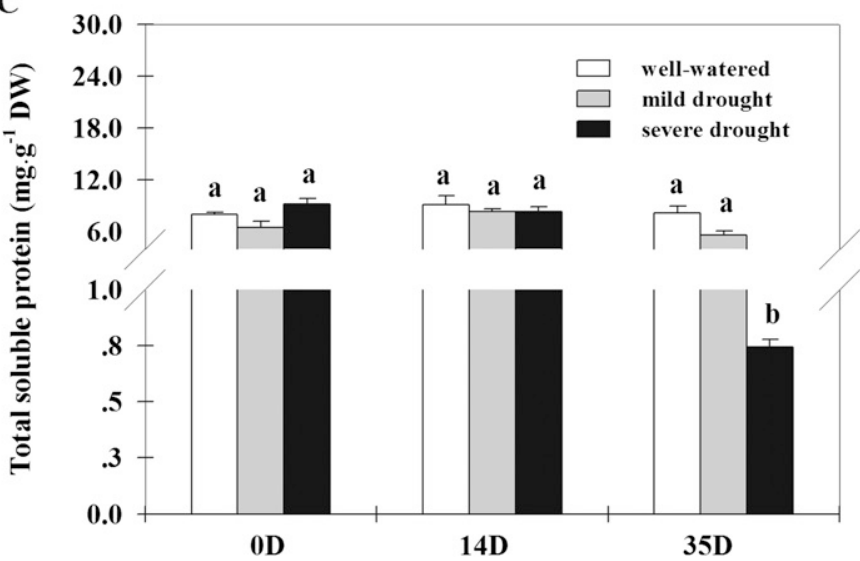

Fig. 2. Responses of proline (A), total soluble sugar (B), and total soluble protein $(\mathbf{C})$ to soil moisture treatments in creeping bentgrass. $0 \mathrm{D}, 14 \mathrm{D}$, and $35 \mathrm{D}$ represent 0,14 , and $35 \mathrm{~d}$ of treatment, respectively. Data represent the mean $\pm \operatorname{SE}(n=4)$. Bars within each sampling date marked with same letters are not significantly different based on the Fisher's protected least significance difference test at $P \leq 0.05$.

content increased by 1.4-fold in the grass under well-watered, remained unchanged under mild drought, and decreased by $71 \%$ under severe drought stress. At day 35 , the grass under well-watered and mild drought conditions had higher proline content than that under severe drought conditions.

Soil moisture treatments did not impact on TSS content from days 0 to 14 (Fig. 2B). The TSS content was increased by 2.5-fold under well-watered and 1.7-fold under mild drought stress, but reduced by $70 \%$ in the grass under severe drought stress during cold acclimation. At day 35, the TSS content was 7.8-fold greater in the grass under mild drought relative to that under severe drought stress, and 36\% lower in the grass under mild drought stress relative to well-watered conditions (Fig. 2B).

The TSP content decreased under severe drought stress, remained unchanged under mild drought and well-watered conditions during cold acclimation (Fig. 2C). At day 35, the TSP content was lower in the grass under severe drought stress relative to that under either well-watered or mild drought stress conditions.

LEAF ROS CONTENT AND LIPID PEROXIDATION. The $\mathrm{O}_{2}{ }^{-}$ content increased by $75 \%$ for the grass under mild drought and $132 \%$ for the grass under severe drought from days 0 to 14 (Fig. 3A). At day $14, \mathrm{O}_{2}^{-}$content was $46 \%$ higher in the grass under severe drought than that under mild drought stress conditions. The $\mathrm{O}_{2}{ }^{-}$increased by $2.9-$ and 1.6 -fold in the grass under well-watered and mild drought stress conditions, respectively, during cold acclimation. At day $35, \mathrm{O}_{2}{ }^{-}$content was lower in the grass under mild drought stress relative to that under either well-watered or severe drought stress condition.

Severe drought stress increased $\mathrm{H}_{2} \mathrm{O}_{2}$ content from days 0 to 14 (Fig. 3B). At day 14, $\mathrm{H}_{2} \mathrm{O}_{2}$ content was 1.7 -fold higher in the grass under severe drought relative to that well-watered condition. The $\mathrm{H}_{2} \mathrm{O}_{2}$ content increased in all treatments regardless of soil moisture during cold acclimation. At day 35, the $\mathrm{H}_{2} \mathrm{O}_{2}$ content was $70 \%$ higher in the grass under severe drought stress condition relative to that under either.

Soil moisture treatments did not affect the MDA content from days 0 to 14 (Fig. 3C). The MDA content was increased by $100 \%, 70 \%$, and $130 \%$ in the grass under well-watered, mild drought, and severe drought stress, respectively, during cold acclimation. At day 35, the grass under severe drought stress had higher MDA content relative to those under well-watered and mild drought conditions.

Antioxidant enZYme activity. The SOD activity decreased in response to mild drought and severe drought stress from days 0 to 14 (Fig. 4A). At day 14, the grass under mild and severe drought stress had lower SOD activity than that under wellwatered conditions. The SOD activity increased in the grass under mild drought and severe drought condition, but decreased in the grass under well-watered conditions during cold acclimation. At day 35, the SOD activity was higher in the grass under mild drought stress relative to those under well-watered or mild drought stress conditions.

The CAT activity increased in the grass under severe drought conditions, remained unchanged under well-watered and mild drought conditions from days 0 to 14 (Fig. 4B). The CAT activity increased in the grass under well-watered and mild drought conditions, remained unchanged under severe drought conditions during cold acclimation. At day 35, the grass under well-watered and mild drought stress conditions had higher CAT activity relative to that under severe drought stress conditions. No difference in CAT activity was found between well-watered and mild drought stress treatment.

The POD activity increased in the grass under severe drought conditions, but remained unchanged under wellwatered and mild drought conditions from days 0 to 14 (Fig. 4C). The POD activity was increased by $38 \%$ in the grass under mild drought stress, but decreased under well-watered, and remained unchanged under severe drought conditions, during 
A

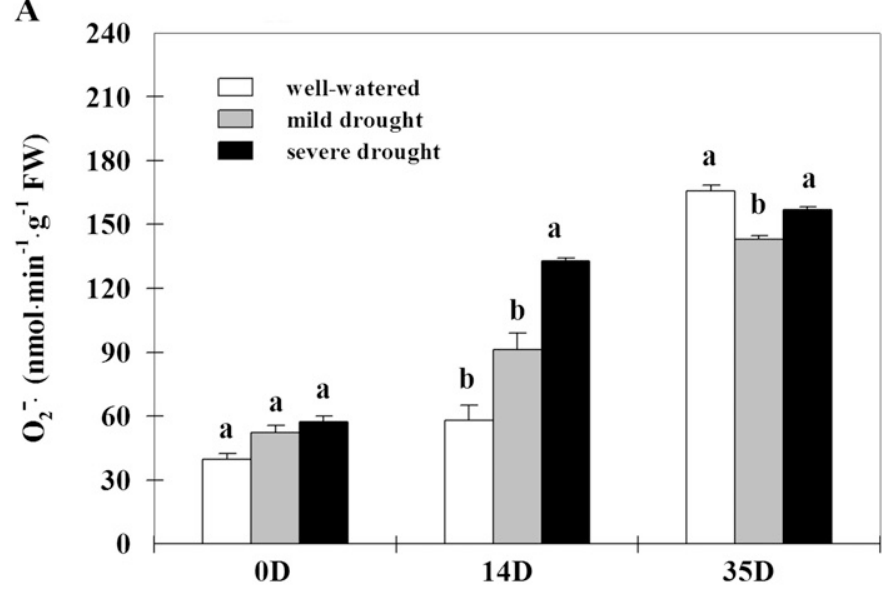

B

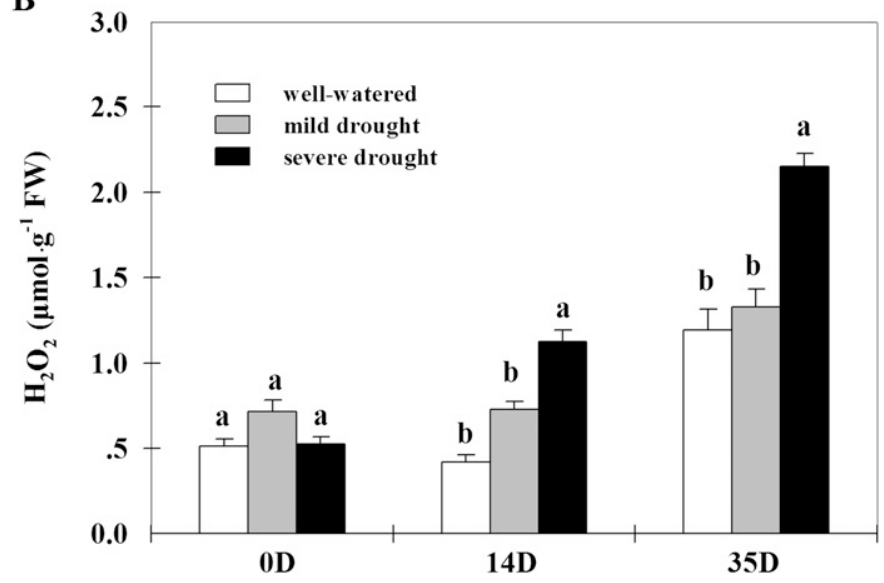

C

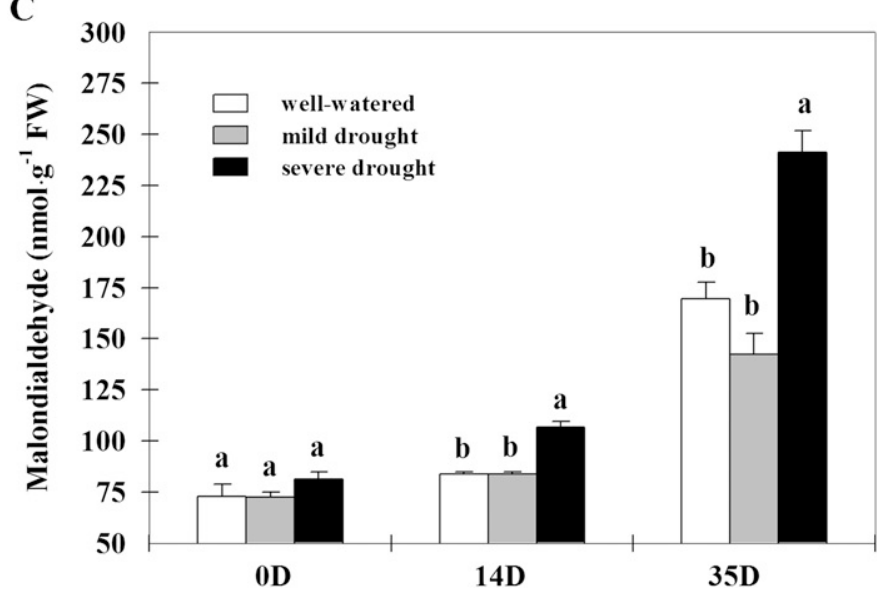

Fig. 3. Responses of superoxide radical $\left[\mathrm{O}_{2}^{-}(\mathbf{A})\right]$, hydrogen peroxide $\left[\mathrm{H}_{2} \mathrm{O}_{2}(\mathbf{B})\right]$, and malondialdehyde $(\mathbf{C})$ to soil moisture treatments in creeping bentgrass. $0 \mathrm{D}, 14 \mathrm{D}$, and $35 \mathrm{D}$ represent 0,14 , and $35 \mathrm{~d}$ of treatment, respectively. Data represent the mean \pm SE $(n=4)$. Bars within each sampling date marked with same letters are not significantly different based on the Fisher's protected least significance difference test at $P \leq 0.05$.

cold acclimation. At day 35, the grass under mild drought stress had higher POD activity than those either under well-watered or severe drought stress conditions.

The APX activity was decreased by $10 \%$ in the grass under severe drought conditions from days 0 to 14 (Fig. 4D). The
APX activity remained unchanged in all treatments regardless of soil moisture during cold acclimation. At day 35, the grass under well-watered and mild drought stress had higher APX activity than that under severe drought stress conditions (Fig. 4D).

Antioxidant isozyme expression. Six SOD isoforms were detected in the well-watered grass at days 0 and 14, whereas eight SOD isoforms were found in the grass under mild drought and severe drought stress conditions at day 14 (Fig. 5A). Eight SOD isoforms were labeled as SOD1 through SOD8 from the top to the bottom of the gel, whose molecular weights calculated with the assistance of the migration distance of a marker protein were $39.8,34.9,31.7,25.8,17.1,14.9,12.1$, and $11.6 \mathrm{kDa}$, respectively. SOD4 and SOD5 were absent in the well-watered grass at days 0 and 14, and the intensity was enhanced under mild drought and severe drought stress after $14 \mathrm{~d}$ of treatment, and strengthened in all three moisture treatments during cold acclimation (from days 14 to 35 ). The intensity of SOD6 and SOD7 expression increased when plants were exposed to $14 \mathrm{~d}$ of drought and increased further when drought was accompanied by cold acclimation treatment. No stain intensity differences in SOD1, SOD2, SOD3, and SOD8 were found between soil moisture treatments.

One CAT isoform $(67.6 \mathrm{kDa})$ was detected in the grass under severe drought stress at day 14 , and the abundance of CAT was increased in all three soil moisture treatments from days 14 to 35 (Fig. 5B). At day 35, the CAT abundance was greater in the grass under mild drought relative to those under well-watered or severe drought stress conditions.

Five POD isoforms (POD1, POD2, POD3, POD4, and POD5) were found in the well-watered grass at days 14 and 35 in the three soil moisture treatments (Fig. 5C). The abundance of POD3 and POD4 was greater in the grass under well-watered and mild drought stress relative to that under severe drought stress conditions at day 35 . The abundance of POD2, POD3, and POD4 were reduced under severe drought stress conditions during cold acclimation.

\section{Discussion}

The results of this study showed that the mild drought stress $(60 \% \mathrm{CC})$ increased freezing tolerance (lower $\mathrm{LT}_{50}$ value) relative to severe drought stress treatment. No difference in freezing tolerance was found between mild drought stress and well-watered treatment. This is consistent with previous studies by Maier et al. (1994) who reported that reduced water content in st. augustinegrass stolons during winter may facilitate cold acclimation. In addition, exposure of arabidopsis to drought stress resulted in an increase in freezing tolerance (Mäntylä et al., 1995). This suggests deficit irrigation-induced mild drought stress before and during cold acclimation may improve freezing tolerance when compared with severe drought stress in creeping bentgrass.

The results of our research showed that the soil moisture treatments for $14 \mathrm{~d}$ before cold acclimation had no influence on EL, RWC, and chlorophyll content in creeping bentgrass. This is in agreement with previous studies (DaCosta and Huang, 2007; Jiang et al., 2010; Xu et al., 2011). Jiang et al. (2010) found that EL, RWC, and chlorophyll content remained unchanged in prairie junegrass [Koeleria macrantha (Ledeb) J.A. Schultes] after $7 \mathrm{~d}$ of drought stress. Xu et al. (2011) reported that the EL, RWC, and photochemical efficiency $(\mathrm{Fv} / \mathrm{Fm})$ remained unchanged in kentucky bluegrass (Poa pratensis L.) after $10 \mathrm{~d}$ of 
A
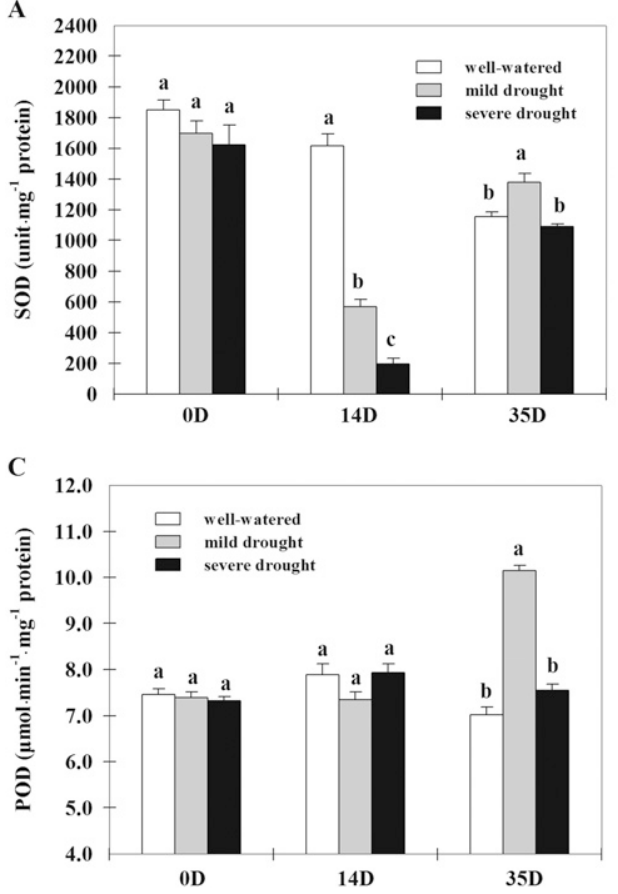

B

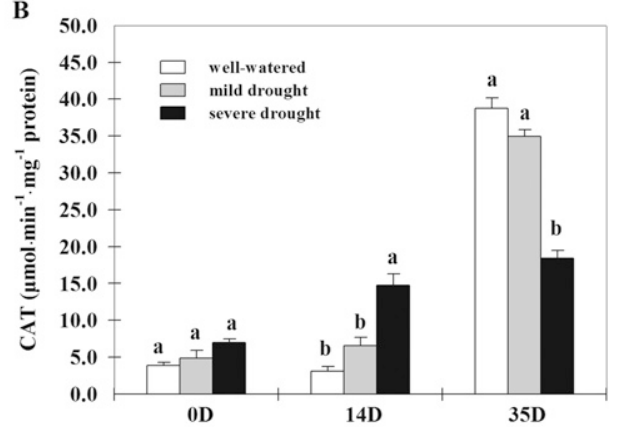

D

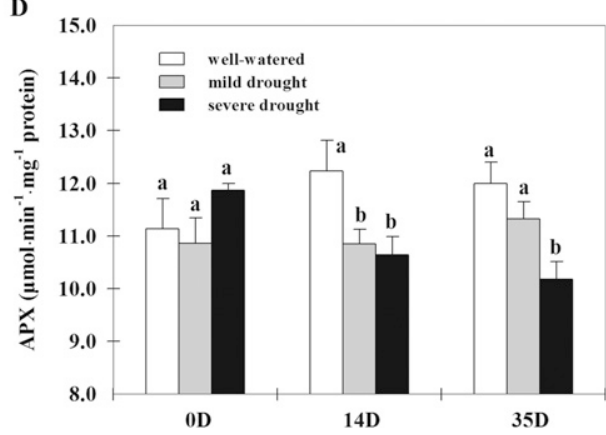

Fig. 4. Responses of superoxide dismutase [SOD (A)], catalase [CAT (B)], guaiacol peroxidase [POD $(\mathbf{C})]$, and ascorbate peroxidase $[\mathrm{APX}(\mathbf{D})]$ to soil moisture treatments in creeping bentgrass. $0 \mathrm{D}, 14 \mathrm{D}$, and $35 \mathrm{D}$ represent 0 , 14 , and $35 \mathrm{~d}$ of treatment, respectively. Data represent the mean $\pm \mathrm{SE}(\mathrm{n}=4)$. Bars within each sampling date marked with same letters are not significantly different based on the Fisher's protected least significance difference test at $P \leq 0.05$.

drought stress. DaCosta and Huang (2007) also found that the RWC of velvet bentgrass (Agrostis canina L.), colonial bentgrass (Arostis capillaris L.), and creeping bentgrass did not change after $14 \mathrm{~d}$ of drought $(30 \% \mathrm{CC})$, but decreased in the third and fourth weeks of drought. This suggests that exposure of grass to drought stress for a short period of time may not cause damage to the plant cell membrane integrity, water status, and chlorophyll.

Our results showed that severe drought stress during cold acclimation (days 14 to 35) increased EL and decreased RWC. In addition, chlorophyll content decreased in response to cold acclimation regardless of soil moisture treatments. Previous studies showed that EL increased consistently in bermudagrass [Cynodon dactylon (L.) Pers (Zhang et al., 2008)] after $21 \mathrm{~d}$ of cold acclimation, and the decline in RWC and chlorophyll content in rice [Oryza sativa L. (Kuk et al., 2003)] under cold treatment. This suggests that drought stress in combination with cold acclimation treatment may cause damage to cell membrane and leaf senescence.

The results of this study showed that the grass under mild drought and well-watered conditions had a lower EL, and higher RWC and chlorophyll content relative to those under severe drought during cold acclimation. This suggests that severe drought stress during cold acclimation may reduce cell membrane integrity and freezing tolerance; in contrast, mild drought stress $(60 \% \mathrm{CC})$ may improve plant water status, cell membrane stability and freezing tolerance.

In our study, TSS and TSP content remained unchanged for all grass under different soil moisture treatments, and proline content improved in the grass under mild drought and severe drought conditions from days 0 to 14. Proline accumulation has also been found in creeping bentgrass and velvet bentgrass
(DaCosta and Huang, 2006) after $15 \mathrm{~d}$ of drought; perennial ryegrass (Lolium perenne L.) and red fescue [Festuca rubra L. (Bandurska and Jóźwiak, 2010)] after $18 \mathrm{~d}$ of drought. Our results suggest that proline may be more sensitive to drought than TSS and TSP.

The results of this study showed that the TSS, TSP, and proline content decreased significantly in the grass under severe drought conditions from days 14 to 35 , but maintained at a higher level in the grass under well-watered and mild drought stress relative to severe drought stress. This suggests that the grass under well-watered and mild drought stress may have better osmotic adjustment relative to that under severe drought stress. Previous studies also showed that TSS and proline increased in perennial ryegrass (Hoffman et al., 2014) during $21 \mathrm{~d}$ of cold acclimation, and zoysiagrass (Zoysia sp.) during $28 \mathrm{~d}$ of cold acclimation (Patton et al., 2007). In addition, Dionne et al. (2001a) reported that TSS, total amino acids, and soluble polypeptides accumulated after cold acclimation at subfreezing temperatures in annual bluegrass. Moreover, the acclimated creeping bentgrass, kentucky bluegrass, and perennial ryegrass had higher proline content relative to the nonacclimated ones (Sarkar et al., 2009). In the previous studies, the plants were exposed to cold acclimation under optimum soil moisture conditions. This suggests cold acclimation itself may induce accumulation of defensive metabolites, and severe drought stress before and during cold acclimation may reduce accumulation of defensive metabolites; in contrast, mild drought stress did not reduce defensive metabolites when compared with wellwatered treatment during cold acclimation.

The results of this study showed that severe drought treatment for $14 \mathrm{~d}$ induced the accumulation of $\mathrm{O}_{2}^{-}$and $\mathrm{H}_{2} \mathrm{O}_{2}$, whereas mild drought stress treatment induced the accumulation of $\mathrm{O}_{2}{ }^{-}$ only. The MDA content remained unchanged in the grass under different moisture treatments from days 0 to 14 . This is consistent with previous studies by Bian and Jiang (2009) and DaCosta and Huang (2007). Bian and Jiang (2009) found that the content of $\mathrm{O}_{2}^{-}$and $\mathrm{H}_{2} \mathrm{O}_{2}$ increased, while MDA content was unchanged in kentucky bluegrass under drought stress; DaCosta and Huang (2007) also reported that the MDA content of velvet bentgrass, colonial bentgrass, and creeping bentgrass did not change after $14 \mathrm{~d}$ of drought. The results of this study suggested that the $\mathrm{O}_{2}{ }^{-}$and $\mathrm{H}_{2} \mathrm{O}_{2}$ during $14 \mathrm{~d}$ of drought may reach a level that activates defense mechanisms without causing cell lipid peroxidation and damage.

In this study, soil moisture treatments and cold acclimation (from days 14 to 35) increased $\mathrm{O}_{2}^{-}, \mathrm{H}_{2} \mathrm{O}_{2}$, and MDA content. The $\mathrm{O}_{2}^{-}$content was lower in the grass under mild drought conditions relative to those under well-watered and severe drought conditions at day 35 . This is consistent with previous 

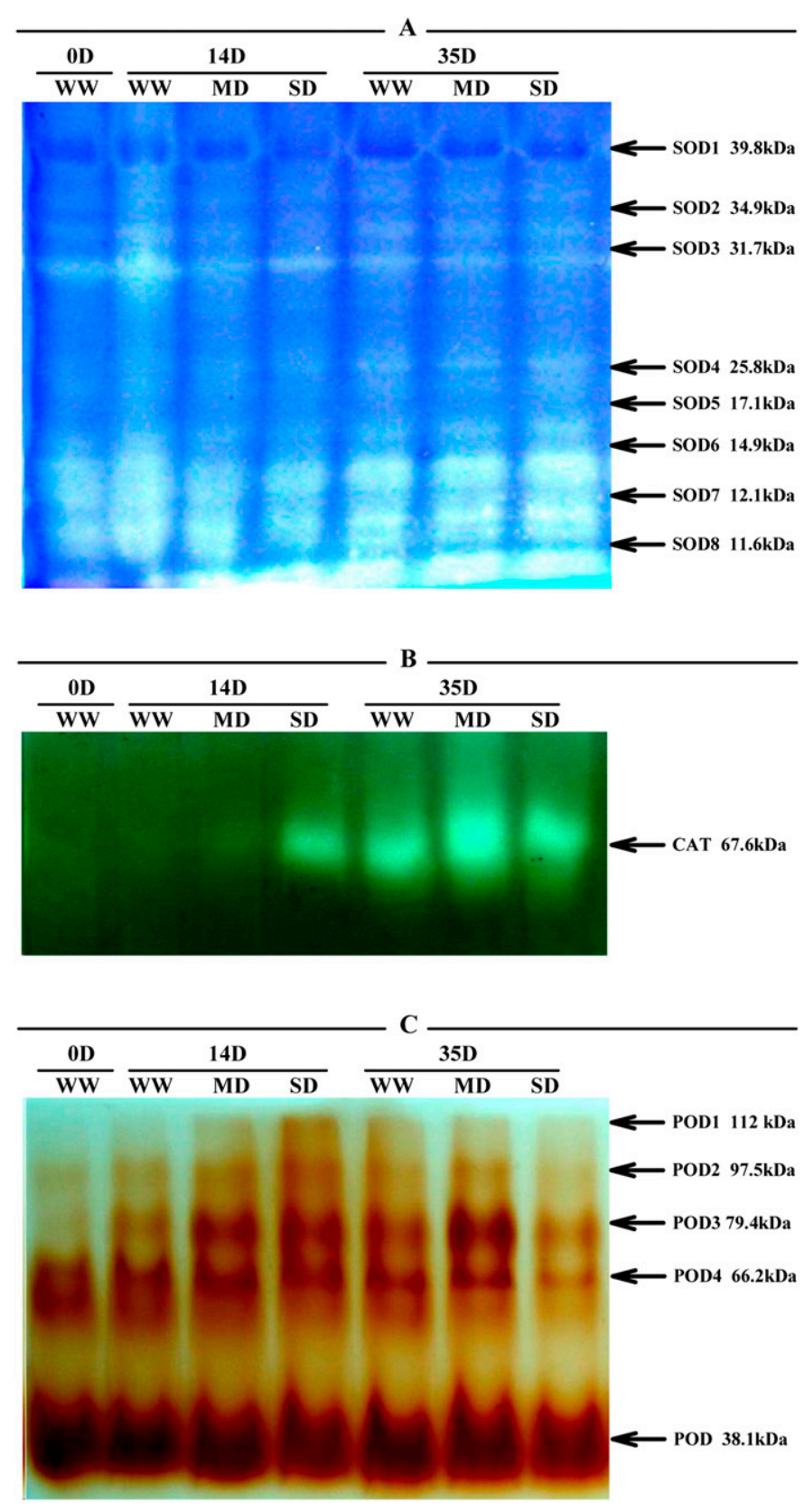

Fig. 5. Changes in expression of antioxidant isozymes in responses to soil moisture treatments in creeping bentgrass: superoxide dismutase [SOD (A)], catalase $[\mathrm{CAT}(\mathbf{B})]$, and guaiacol peroxidase $[\mathrm{POD}(\mathbf{C})] ; \mathrm{WW}=$ well-watered; $\mathrm{MD}=$ mild drought; $\mathrm{SD}=$ severe drought. $0 \mathrm{D}, 14 \mathrm{D}$, and $35 \mathrm{D}$ represent 0,14 , and $35 \mathrm{~d}$ of treatment.

studies in rice (Kuk et al., 2003), maize [Zea mays L. (Prasad et al., 1994)], and tomato [Solanum lycopersicum L. (Zhou et al., 2012)]. This suggests the grass exposed to mild drought stress may develop a strong antioxidant defense system and suppress ROS and lipid peroxidation during cold acclimation. The grass under severe drought stress may accumulate a high level of $\mathrm{O}_{2}{ }^{-}$that causes cell membrane lipid peroxidation. Mild drought treatment may reduce winter-kill, whereas severe drought stress may increase winter-kill of creeping bentgrass because of ROS toxicity.

Plant has developed various antioxidant metabolites and enzymes to cope with toxic ROS and protect cells. The antioxidant defense systems are closely associated with stress tolerance (Hoffman et al., 2014; Huang et al., 2014). Merewitz et al. (2011) noted that the suppression of drought-induced leaf senescence and root dieback in the transgenic creeping bentgrass plants was associated with the maintenance of greater antioxidant enzyme activities. The results of this study showed that the SOD activity decreased in the grass under mild drought and severe drought conditions, and CAT and POD increased in the grass under severe drought after $14 \mathrm{~d}$ of soil moisture treatments. This result is consistent with previous studies in kentucky bluegrass (Xu et al., 2011), creeping bentgrass, colonial bentgrass (DaCosta and Huang, 2007), and wheat [Triticum sp. (Khanna-Chopra and Selote, 2007; Selote and Khanna-Chopra, 2006)]. The reduction of SOD activity may be resulted from its scavenging of $\mathrm{O}_{2}^{-}$(Fig. 3A) produced under drought stress. In this study, mild drought stress did not impact CAT, APX, and POD activity from days 0 to 14 , and increased SOD, CAT, POD, and APX activity from days 14 to 35 . Our results suggested mild drought stress may improve antioxidant defense system during cold acclimation.

In this study, we detected eight SOD isoforms. Drought stress not only induced new isoforms (SOD4 and SOD5), but also enhanced isoform intensity (SOD6 and SOD7) (Fig. 5A). This result is consistent with previous studies by Abedi and Pakniyat (2010) and Srivalli et al. (2003). The results of this study also showed that drought stress in combination with cold acclimation led to increases in SOD isoform intensity (SOD4-SOD7). Similar results were found in shasta daisy [Leucanthemum superbum L. (Zhou et al., 2005)]. One CAT isoform was observed under severe drought stress at days 14 and 35 in this study. The CAT isoform was more abundant under mild drought relative to well-watered and severe drought stress. This is consistent with previous studies by Srivalli et al. (2003) who reported that $13 \mathrm{~d}$ of drought induced a stronger CAT isoform intensity in rice when compared with the wellwatered control. Kuk et al. (2003) detected two CAT isoforms in rice under cold stress. The results of this study suggest cold acclimation in combination with mild drought treatments may enhance expression of CAT isoform. In this study, four POD isoforms were detected under well-watered conditions, and one more isoform was induced by a combination of drought and cold acclimation. This is in agreement with previous studies by Wang and Jiang (2007) and Wang et al. (2012). The data suggests that drought stress in combination with cold acclimation may induce new POD isoforms.

In summary, the results of this study indicated that mild drought stress treatments before and during cold acclimation increased accumulation of osmoprotectants, improved antioxidant metabolism and freezing tolerance when compared with severe drought stress treatment. No difference in freezing tolerance was found between well-watered and mild drought stress treatment. Mild drought stress-induced changes in proline, antioxidant metabolism may be closely associated with improved freezing resistance. The results of this study suggest that deficit irrigation-induced mild drought stress before and during cold acclimation may not only save water and reduce cost but also improve winter survival of creeping bentgrass in the region with limited precipitation in late fall and winter months. Severe drought stress caused by no irrigation may significantly inhibit osmoprotect and antioxidant metabolism, and increased the likelihood of winter-kill of creeping bentgrass. 


\section{Literature Cited}

Abedi, T. and H. Pakniyat. 2010. Antioxidant enzyme changes in response to drought stress in ten cultivars of oilseed rape. Czech J. Genet. Plant Breed. 46:27-34.

Aebi, H. 1984. Catalase in vitro. Methods Enzymol. 105:121-126.

Allen, R.D. 1995. Dissection of oxidative stress tolerance using transgenic plants. Plant Physiol. 107:1049-1054.

Apel, K. and H. Hirt. 2004. Reactive oxygen species: Metabolism, oxidative stress, and signal transduction. Annu. Rev. Plant Biol. 55:373-399.

Ball, S., Y. Qian, and C. Stushnoff. 2002. Soluble carbohydrates in two buffalograss cultivars with contrasting freeze tolerance. J. Amer. Soc. Hort. Sci. 127:45-49.

Bandurska, H. and W. Jóźwiak. 2010. A comparison of the effects of drought on proline accumulation and peroxidases activity in leaves of Festuca rubra and Lolium perenne L. Acta Societatis Botanicorum Poloniae 79:111-116.

Banowetz, G.M., K.P. Dierksen, M.D. Azevedo, and R. Stout. 2004. Microplate quantification of plant leaf superoxide dismutases. Anal. Biochem. 332:314-320.

Beard, J.B. 1973. Turfgrass: Science and culture. Prentice Hall, Englewood Cliffs, NJ.

Beauchamp, C. and I. Fridovich. 1971. Superoxide dismutase: Improved assays and an assay applicable to acrylamide gels. Anal. Biochem. 44:276-287.

Bhowmik, P.C., K. Shetty, and D. Sarkar. 2008. Cold-stress response of cool-season turfgrass: Antioxidant metabolism, p. 507-530. In: M. Pessarakli (ed.). Handbook of turfgrass management and physiology. CRC Press, New York, NY.

Bian, S.M. and Y.W. Jiang. 2009. Reactive oxygen species, antioxidant enzyme activities and gene expression patterns in leaves and roots of kentucky bluegrass in response to drought stress and recovery. Sci. Hort. 120:264-270.

Black, C.A. 1965. Methods of soil analysis: Part I Physical and mineralogical properties. Amer. Soc. Agron., Madison, WI.

Blokhina, O., E. Virolainen, and K.V. Fagerstedt. 2003. Antioxidants, oxidative damage and oxygen deprivation stress: A review. Ann. Bot. 91:179-194.

Bradford, M.M. 1976. A rapid and sensitive method for the quantitative determination of microgram quantities of protein utilizing the principle of protein-dye binding. Anal. Biochem. 7:248-254.

DaCosta, M. and B.R. Huang. 2006. Osmotic adjustment associated with variation in bentgrass tolerance to drought stress. J. Amer. Soc. Hort. Sci. 131:338-344.

DaCosta, M. and B.R. Huang. 2007. Changes in antioxidant enzyme activities and lipid peroxidation for bentgrass species in response to drought stress. J. Amer. Soc. Hort. Sci. 132:319-326.

Dionne, J., Y. Castonguay, P. Nadeau, and Y. Desjardins. 2001a. Amino acid and protein changes during cold acclimation of green-type annual bluegrass (Poa annua L.) ecotypes. Crop Sci. 41:1862-1870.

Dionne, J., Y. Castonguay, P. Nadeau, and Y. Desjardins. 2001b. Freezing tolerance and carbohydrate changes during cold acclimation of green-type annual bluegrass (Poa annua L.) ecotypes. Crop Sci. 41:443-451.

Ervin, E.H., A. LaBranche, and X. Zhang. 2009. Kentucky bluegrass and creeping bentgrass responses to foliar application of glycinebetaine at three ET replacement level. Intl. Turfgrass Soc. Res. J. 11:755-764.

Fielding, J.L. and J.L. Hall. 1978. A biochemical and cytochemical study of peroxidase activity in roots of Pisum sativum. J. Expt. Bot. 29:969-981.

Fu, J.M. and P.H. Dernoeden. 2009. Creeping bentgrass putting green turf responses to two summer irrigation practices: Quality, chlorophyll, canopy temperature, and thatch-mat. Crop Sci. 49:1071-1078.

Gusta, L.V., J.D. Butler, C. Rajashekar, and M.J. Burke. 1980. Freezing resistance of perennial turfgrasses. HortScience 15:494496.
Hoffman, L., M. DaCosta, A. Bertrand, Y. Costonguay, and S. Ebdon. 2014. Comparative assessment of metabolic responses to cold acclimation and deacclimation in annual bluegrass and creeping bentgrass. Environ. Expt. Bot. 106:197-206.

Hoffman, L., M. DaCosta, S. Ebdon, and E. Watkins. 2010. Physiological changes during cold acclimation of perennial ryegrass accessions differing in freeze tolerance. Crop Sci. 50:1037-1047.

Huang, B.R., M. DaCosta, and J. Jiang. 2014. Research advances in mechanisms of turfgrass tolerance to abiotic stresses: From physiology to molecular biology. Crit. Rev. Plant Sci. 33:141-189.

Jiang, Y.W., W. Eric, S.W. Liu, X.Q. Yu, and N. Luo. 2010. Antioxidative responses and candidate gene expression in prairie junegrass under drought stress. J. Amer. Soc. Hort. Sci. 135:303309.

Jiang, M.Y. and J.H. Zhang. 2001. Effect of abscisic acid on active oxygen species, antioxidative defense system and oxidative damage in leaves of maize seedlings. Plant Cell Physiol. 42:1265-1273.

Khanna-Chopra, R. and D.S. Selote. 2007. Acclimation to drought stress generates oxidative stress tolerance in drought-resistant than -susceptible wheat cultivar under field conditions. Environ. Expt. Bot. 60:276-283.

Kochhar, S., V.K. Kochhar, and S.D. Khanduja. 1979. Changes in the pattern of isoperoxidases during maturation of grape berries $\mathrm{cV}$ Gulabi as affected by ethephon (2-chloroethyl) phosphonic acid. Amer. J. Enol. Viticult. 30:275-277.

Kuk, Y.I., J.S. Shin, N.R. Burgos, T.E. Hwang, O. Han, B.H. Cho, S.Y. Jung, and J.O. Guh. 2003. Antioxidative enzymes offer protection from chilling damage in rice plants. Crop Sci. 43:2109-2117.

Maier, F.P., N.S. Lang, and J.D. Fry. 1994. Freezing tolerance of three st. augustinegrass cultivars as affected by stolon carbohydrate and water content. J. Amer. Soc. Hort. Sci. 119:473-476.

Mäntylä, E., V. Lång, and E.T. Palva. 1995. Role of abscisic acid in drought-induced freezing tolerance, cold acclimation, and accumulation of LT178 and RABI 8 proteins in A. thaliana. Plant Physiol. 107:141-148.

McCann, S.E. and B.R. Huang. 2007. Effects of trinexapac-ethyl in creeping bentgrass responses to combined drought and heat stress. Crop Sci. 47:2121-2128.

Menezes-Benavente, L., F.K. Teixeira, C.L.A. Kamei, and M. MargisPinheiro. 2004. Salt stress induces altered expression of genes encoding antioxidant enzymes in seedlings of a Brazilian indica rice (Oryza sativa L.). Plant Sci. 166:323-331.

Merewitz, E.B., T. Gianfagna, and B.R. Huang. 2011. Protein accumulation on leaves and roots associated with improved drought tolerance in creeping bentgrass expressing an ipt gene for cytokinin synthesis. J. Expt. Bot. 62:5311-5333.

Mittler, R. 2002. Oxidative stress, antioxidants, and stress tolerance. Trends Plant Sci. 7:405-410.

Møller, I.M., P.E. Jensen, and A. Hansson. 2007. Oxidative modifications to cellular components in plants. Annu. Rev. Plant Biol. 58:459-481.

Nakano, Y. and K. Asada. 1981. Hydrogen peroxide is scavenged by ascorbate-specific peroxidase in spinach chloroplasts. Plant Cell Physiol. 22:867-880.

Nemali, K.S., F. Montesano, S.K. Dove, and M.W. van Iersel. 2007. Calibration and performance of moisture sensor in soilless substrates: $\mathrm{ECH}_{2} \mathrm{O}$ and theta probes. Sci. Hort. 112:227-234.

Patton, A.J., S.M. Cunningham, J.J. Volenec, and Z.J. Reicher. 2007. Differences in freeze tolerance of zoysiagrasses: II. Carbohydrate and proline accumulation. Crop Sci. 47:2170-2181.

Prasad, T.K., M.D. Anderson, B.A. Martin, and C.R. Stewart. 1994. Evidence for chilling-induced oxidative stress in maize seedlings and a regulatory role for hydrogen peroxide. Plant Cell 6:65-74.

Sarkar, D., P.C. Bhowmik, K. Young-In-Kwon, and K. Shetty. 2009. Cold acclimation responses of three cool-season turfgrasses and the role of proline-associated pentose phosphate pathway. J. Amer. Soc. Hort. Sci. 134:210-220. 
Selote, D.S. and R. Khanna-Chopra. 2006. Drought acclimation confers oxidative stress tolerance by inducing coordinated antioxidant defense at cellular and subcellular level in leaves of wheat seedlings. Physiol. Plant. 127:494-506.

Sergiev, I., V. Alexieva, and E. Karanov. 1997. Effect of spermine, atrazine and combination between them on some endogenous protective systems and stress markers in plant. Comptes Rendus de $\mathrm{L}$ Academie Bulgare des Sciences 51:121-124.

Shi, H.T., Y.P. Wang, Z.M. Cheng, T.T. Ye, and Z.L. Chan. 2012. Analysis of natural variation in bermudagrass (Cynodon dactylon) reveals physiological responses underlying drought tolerance. PLoS ONE 7:1-12.

Smirnoff, N. 1993. The role of active oxygen in the response of plants to water-deficit and desiccation. New Phytol. 125:27-58.

Srivalli, B., G. Sharma, and R. Khanna-Chopra. 2003. Antioxidative defense system in an upland rice cultivar subjected to increasing intensity of water stress followed by recovery. Physiol. Plant. 119:503-512.

Wang, K.H. and Y.W. Jiang. 2007. Antioxidant responses of creeping bentgrass roots to waterlogging. Crop Sci. 47:232-238.
Wang, K.H., X.Z. Zhang, and E. Ervin. 2012. Antioxidative responses in roots and shoots of creeping bentgrass under high temperature: Effects of nitrogen and cytokinin. J. Plant Physiol. 169:492-500.

Woodbury, W., A.K. Spencer, and M.A. Stahmann. 1971. An improved procedure using ferricyanide for detecting catalase isozymes. Anal. Biochem. 44:301-305.

$\mathrm{Xu}$, L.X., L.B. Han, and B.R. Huang. 2011. Antioxidant enzyme activities and gene expression patterns in leaves of kentucky bluegrass in response to drought and post-drought recovery. J. Amer. Soc. Hort. Sci. 136:247-255.

Zhang, X.Z., K.H. Wang, and E.H. Ervin. 2008. Bermudagrass freezing tolerance associated with abscisic acid metabolism and dehydrin expression during cold acclimation. J. Amer. Soc. Hort. Sci. 133:542-550.

Zhou, J., J. Wang, K. Shi, X.J. Xia, Y.H. Zhou, and J.Q. Yu. 2012. Hydrogen peroxide is involved in the cold acclimation-induced chilling tolerance of tomato plants. Plant Physiol. Biochem. 60:141-149.

Zhou, S.P., R.J. Sauvé, M.T. Mmbaga, and C. Frenkel. 2005. Coldinduced antioxidant enzymes changes in Leucanthemum maximum 'Silver Princess'. HortScience 40:546-548. 